\title{
Influence of the level of socio-economic development of regions on demographic and migration processes
}

\author{
A. E. Chistyakov ${ }^{1}$, A. V. Shustov ${ }^{1}$
}

${ }_{1}^{1}$ P. G. Demidov Yaroslavl State University, 14 Sovetskaya str., Yaroslavl 150003, Russian Federation

DOI: $10.18255 / 2412-6519-2020-1-66-81$

Research Article

Full text in Russian

The article deals with the problem of the influence of the level of socio-economic development of Russian regions on demographic and migration processes. The relationship between economic indicators, the total population growth in the regions and its componentsnatural and migration growth during 2000-2017 are analyzed. The authors reveals the relationship between the dynamics of the gross regional product (GRP) and the population of the regions, as well as the factors that determine these processes.

For the purposes of the study, a sample of "typical" regions was formed. In the process of its formation, national autonomies and remote territories with a more severe climate were excluded from the total number of subjects of the Russian Federation, where the development of demographic and migration processes may be determined by "atypical" factors for other regions of the Russian Federation (national-cultural, climatic, etc.).

The article analyzes the causes of internal migration and features of socio-demographic development of subjects of the Russian Federation. The role of the Moscow region as an object of migration attraction is investigated, and the factors that deter and stimulate internal migration are considered. The official data of the Federal state statistics service for 2000-2017 were used as an information base for the study.

Keywords: migration; population; regions; GRP; natural growth; social and economic development

\section{INFORMATION ABOUT THE AUTHORS}

Chistyakov Alexander E. $\mid$ E-mail: alex-ch7@mail.ru

(correspondence author) Candidate of Sciences in Economics

\begin{tabular}{l|l} 
Shustov Alexander V. & $\begin{array}{l}\text { E-mail: a.v.shustov@yandex.ru } \\
\text { Candidate of Sciences in History }\end{array}$
\end{tabular}

For citation: Chistyakov A. E., Shustov A. V. Influence of the level of socio-economic development of regions on demographic and migration processes // Social'nye i gumanitarnye znanija. 2020. Vol. 6, No 1. P. 66-81. (in Russ.)

(C) Chistyakov A. E., Shustov A. V., 2020

This is an open access article under the CC BY-NC-ND license (http://creativecommons.org/licenses/by-nc-nd/4.0/) 


\title{
Влияние уровня социально-экономического развития регионов на демографические и миграционные процессы
}

\author{
А. Е. Чистяков ${ }^{1}$, А. В. Шустов ${ }^{1}$
}

1Ярославский государственный университет им. П. Г. Демидова, ул. Советская, 14, Ярославль, 150003, Российская Федерация

DOI: $10.18255 / 2412-6519-2020-1-66-81$

УдК 314
Научная статья

Полный текст на русском языке

В статье рассматривается проблема влияния уровня социально-экономического развития регионов РФ на демографические и миграционные процессы, протекающие на их территории. С этой целью анализируется взаимосвязь экономических показателей, общего прироста населения регионов и его компонентов - естественного и миграционного прироста - на протяжении 2000-2017 гг. Выявляются зависимости между динамикой валового регионального продукта (ВРП) и численностью населения регионов, а также определяющие эти процессы факторы.

Для целей исследования была сформирована выборка “типичных" регионов. В процессе ее формирования из общего числа субъектов РФ были исключены национальные автономии и отдаленные территории с более суровым климатом, где развитие демографических и миграционных процессов может определяться «нетипичными» для других регионов РФ (национально-культурными, климатическими и т. п.) факторами.

Анализируются причины внутренней миграции и особенности социально-демографического развития отдельных субъектов РФ. Исследуется роль московского региона (Москва и Московская область) в качестве объекта миграционного притяжения, рассматриваются сдерживающие и стимулирующие внутреннюю миграцию факторы. В качестве информационной базы исследования использованы официальные данные Федеральной службы государственной статистики за 2000-2017 гг.

Ключевые слова: миграция; население; регионы; ВРП; естественный прирост; социальноэкономическое развитие

ИНФОРМАЦИЯ ОБ АВТОРАХ

$$
\begin{array}{r|l}
\text { Чистяков Александр } & \text { E-mail: alex-ch7@mail.ru } \\
\text { Евгеньевич } & \text { Кандидат экономических наук, доцент кафедры социологии } \\
\text { (автор для корреспонденции) } & \\
\text { Шустов Александр } & \text { E-mail: a.v.shustov@yandex.ru } \\
\text { Владимирович } & \text { Кандидат исторических наук, доцент кафедры социологии }
\end{array}
$$

Для цитирования: Чистяков А. Е., Шустов А. В. Влияние уровня социально-экономического развития регионов на демографические и миграционные процессы // Социальные и гуманитарные знания. 2020. Том 6, № 1. С. 66-81.

(C) Чистяков А. Е., Шустов А. В., 2020

Статья открытого доступа под лицензией СC BY-NC-ND (http://creativecommons.org/licenses/by-nc-nd/4.0/) 


\section{Введение}

Демографическое развитие регионов относится к числу ключевых проблем, с которыми пришлось столкнуться современной России. Неравномерное распределение населения по территории страны, западный «дрейф» миграций и их ориентация на несколько крупных агломераций, угроза обезлюживания удаленных от центра регионов Сибири, Дальнего Востока и других приграничных областей, усугубляемые суровым климатом, разницей в уровне доходов и качестве жизни, сделали демографическое развитие территорий крайне актуальной научной, общественнополитической и практической проблемой, которая находится в зоне пересечения интересов демографии, социологии и экономики и других общественных наук.

Вопрос о том, насколько уровень социально-экономического развития влияет на демографические и миграционные процессы, определяющие изменение численности населения, относится к числу ключевых проблем социологии и демографии. Между тем ставится он, как правило, в разрезе уровня жизни семей и их способности (и желания) прокормить определенное число детей. Влияние макроэкономических показателей на динамику численности населения рассматривается гораздо реже, поскольку их роль, по-видимому, считается более абстрактной и опосредованной, чем доходы домохозяйств. Однако доходы эти формируются прежде всего именно под влиянием макроэкономических показателей и общего уровня социально-экономического развития региона.

Исследование влияния экономических показателей на динамику численности населения регионов РФ, включая ее ключевые факторы - естественный и миграционный прирост, - и является целью данной статьи.

\section{Исследования проблемы}

Проблема влияния социально-экономических процессов на численность населения регионов России, а также ее компоненты - естественный и миграционный прирост -находится на стыке как минимум трех научных дисциплин: демографии, экономики и социологии. Причем экономисты, рассматривающие воздействие экономических показателей на различные аспекты общественной жизни, а также демографы, изучающие пространственные аспекты демографической и миграционной динамики, уделяют этой теме гораздо больше внимания, чем социологи, которых, как правило, интересуют внутрисоциальные факторы рождаемости, смертности, миграции и других процессов, влияющих на численность населения.

Внимание к вопросам взаимосвязи социально-экономических процессов и динамики численности населения обусловлено, прежде всего, демографическим кризисом, который развивается в России с 1960-х гг. в латентной, а с начала 1990-х гг. в «открытой» форме. Несмотря на значительное повышение рождаемости во второй половине «нулевых» - первой половине «десятых» годов, кризис этот так и не преодолен окончательно, а в последнее время демографическая и миграционная ситуация в России приобретает все более тревожные черты. Все эти негативные процессы стали объектом исследований, авторы которых попытались найти решение нарастающих проблем.

В социально-демографических исследованиях отмечается неравномерность протекания воспроизводственных и миграционных процессов в регионах России, 
следствием чего является отток населения из периферийных, в том числе геополитически значимых для страны регионов, его концентрация в столицах и крупных мегаполисах [1]. В качестве важнейшего фактора формирования внутренних миграционных потоков, усугубляющего негативные тенденции территориального перераспределения населения, рассматривается социально-экономическая дифференциация регионов и порождаемые ею различия в уровне жизни и доходов населения. При этом Россия, ставшая главным объектом притяжения неквалифицированных иммигрантов из стран СНГ, сама превратилась в донора квалифицированных эмигрантов для стран с развитой экономикой [2].

В «периферийных» регионах Центрального и Северо-западного федеральных округов, объединяемых понятием «Ближний Север России», превышение смертности над рождаемостью и стягивание населения в столицы ведет к устойчивому сокращению его численности. Как отмечают М. Б. Денисенко и У. Г. Николаева, по темпам сокращения населения Костромская область и ряд других областей Центральной России сегодня опережают большинство регионов Сибири и Дальнего Востока. Территориальная дифференциация в протекании воспроизводственных и миграционных процессов наблюдается и внутри областей «Ближнего Севера», где более благополучными выглядят региональный центр и прилегающий к нему муниципальный район $[3$, с. 80].

Трактовки причин переживаемого Россией демографического кризиса отчетливо смещаются от социально-экономических к ментально-психологическим факторам, связанным с урбанизацией, и вызванными ею изменениями в образе жизни, отношении к институту брака, семьи и рождению детей. Диссонансом на фоне продолжающейся в РФ депопуляции выглядят среднеазиатские страны СНГ и некоторые северокавказские автономии России с преобладающим мусульманским населением, которые, несмотря на более низкий уровень жизни, сохраняют высокую рождаемость. На фоне переживаемого странами ЕС миграционного кризиса приток населения из этих регионов, как отмечают Е. Б. Яковлева и О. Е. Кислова, может повлечь за собой схожие последствия, породив неприятие мигрантов со стороны принимающего общества и «социальные взрывы» [4, с. 18].

Сложность и противоречивость миграционных проблем побудили исследователей к поиску объяснительных моделей, в рамках которых они пытались найти взаимосвязи между миграцией и различными социально-экономическими показателями. Первая такая попытка, предпринятая в начале 1990-х гг. М. Б. Денисенко, показала, что зависимость между уровнем безработицы и миграционным приростом населения в России на уровне регионов отсутствует. Однако ему удалось обнаружить «относительно удовлетворительную» взаимосвязь между миграцией и денежными доходами населения [Цит. по: 5, с. 114]. Схожая ситуация продолжала существовать и в середине «нулевых» годов, когда, по словам Л. Б. Карачуриной, только расчеты парных корреляций между различными социально-экономическими индикаторами и интенсивностью прибытий взаимосвязи между этими показателями не обнаруживали. Хотя такие индикаторы, как сальдо миграции и интенсивность прибытия, рассматривались ею как важный индикатор социально-экономической ситуации в регионе.

Как показал факторный анализ миграционной подвижности населения РФ, большинство переселенческих потоков между федеральными округами сильно кор- 
релируют друг с другом [6]. В числе факторов, определяющих миграционную активность населения и направления его перемещений, большое внимание сегодня уделяется обеспеченности жильем, а также возможности его приобретения или аренды [7].

При этом единственным значимым экономическим фактором, воздействующим на миграционные передвижения населения ЦФО на уровне муниципалитетов, по расчетам Д. Н. Мокренского, оказался уровень среднемесячной заработной платы, который, впрочем, влияет на миграции не очень сильно. Показатели уровня доходов местных бюджетов, инвестиций и количества отгруженных товаров на миграционные перемещения населения не влияют, а средняя численность работников организаций воздействует на них отрицательно [8].

К примечательным выводам в ходе исследования влияния миграции на заработные платы, безработицу и среднедушевые доходы населения регионов РФ пришел Е. С. Вакуленко. По его оценкам, эмиграция из регионов приводит к росту зарплат и среднедушевых доходов населения. А поскольку мигранты перемещаются из менее благополучных регионов в более развитые, то получается, что следствием эмиграции является выравнивание заработных плат и среднедушевых доходов. При этом на уровень безработицы миграция никакого значимого влияния не оказывает [9].

Большинство авторов, впрочем, отмечают, что их исследования являются лишь первыми шагами в плане изучения взаимосвязи демографических, миграционных и социально-экономических процессов на уровне регионов как из-за возможной неполноты статистических данных, особенно по миграции, так и из-за невозможности учесть в экономико-демографических моделях все значимые факторы.

\section{Методы исследования}

В качестве интегрального показателя экономического развития территории в исследовании был использован валовой региональный продукт на душу населения, который тесно связан с уровнем среднедушевых денежных доходов населения. Но в отличие от них подушевой ВРП является более интегральным индикатором, поскольку: 1) среднедушевые денежные доходы населения хуже поддаются учету; 2) ВРП учитывает инвестиционную активность, что в перспективе отражается на количестве рабочих мест и уровне доходов, способствуя притоку населения в регион.

В качестве точки отсчета современного демографического и социально-экономического развития России принят 2000 год. На рубеже 1990-х и «нулевых» годов в стране начался значительный экономический рост, что означало разворот негативного тренда предыдущего десятилетия. К числу исследуемых демографических показателей относятся общий, естественный и миграционный прирост населения. Последний из них рассчитывался как разность между общим и естественным приростом. Источником для расчетов послужили демографические и экономические данные Росстата [10].

В итоговую выборку включено 57 субъектов РФ. Те регионы, которые имеют в своем составе «внутренние автономии», рассматривались отдельно. Так, например, Архангельская и Тюменская области анализировались без автономных округов. Из выборки были исключены субъекты РФ, на уровень рождаемости в которых заметное влияние оказывают национально-религиозные традиции (Чечня, Дагестан, Ингушетия, Алтай, Якутия, Калмыкия, Коми, Адыгея, Кабардино-Балкарская Республика, Тыва, Хакасия, Бурятия, Карачаево-Черкесия, Северная Осетия, Башкирия, Та- 
тарстан). По тем же причинам в выборку не были включены Астраханская и Оренбургская области, где заметную часть населения (15 \% и более) составляют представители азиатских этносов.

Ряд отдаленных регионов Крайнего Севера и Дальнего Востока (Сахалинская область, Магаданская область, Камчатский край, Мурманская область, Ненецкий, Ямало-Ненецкий, Ханты-Мансийский, Чукотский автономные округа) были исключены из выборки в силу территориальной удаленности и сурового климата, делающих их крайне малопривлекательны для проживания, что должно компенсироваться более высокими доходами. В этих субъектах РФ отмечен высокий уровень подушевого ВРП и денежных доходов населения и одновременно высокий уровень цен, что затрудняет их сравнение с другими регионами. В то же время в состав выборки включены Удмуртия, Чувашия, Марий Эл и Мордовия, которые в культурно-этническом плане мало отличимы от остальных регионов РФ.

\section{Общий и естественный прирост населения}

Анализ взаимосвязи общего прироста населения с 2000 по 2017 гг. и подушевого ВРП регионов за 2016 г. (рис. 1) показывает наличие четкой зависимости между этими показателями. В целом между регионами имеется значительный разброс значений как по экономическим, так и по демографическим индикаторам. Большинство субъектов РФ имеет отрицательный прирост населения, а среди регионов с положительным приростом также наблюдается значительный разброс значений по подушевому ВРП.

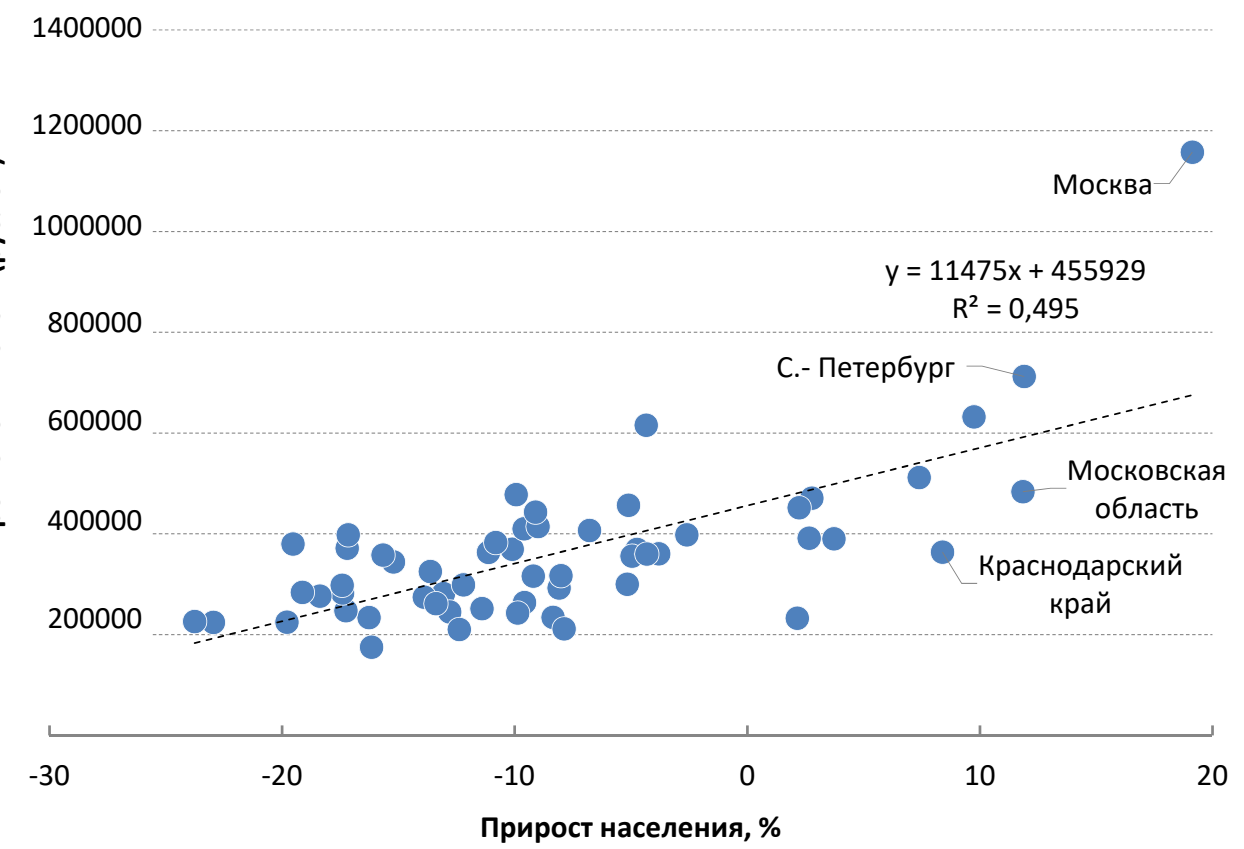

Рисунок 1. Зависимость прироста населения от подушевого ВРП. 
При этом зависимость между ВРП и динамикой населения выглядит следующим образом: прирост подушевого ВРП на 11000 рублей (примерно по уравнению регрессии) означает прирост населения (или сокращение убыли) за 18 лет на 1 \%.

Ключевым показателем интенсивности рождаемости, свободным от влияния половозрастной структуры населения, является суммарный коэффициент рождаемости (СКР), который представляет собой число рождений в расчете на одну женщину в репродуктивном возрасте. Между тем анализ его взаимосвязи с ВРП субъектов РФ показывает, что зависимость между этими показателями отсутствует (рис. 2). В лидирующем по уровню ВРП регионе - Москве - отмечен один из самых низких показателей СКР, что, впрочем, может быть следствием не только макроэкономических, но и других факторов (низкий уровень обеспеченности жильем, особенности образа жизни, «столичного» менталитета и т. п.).

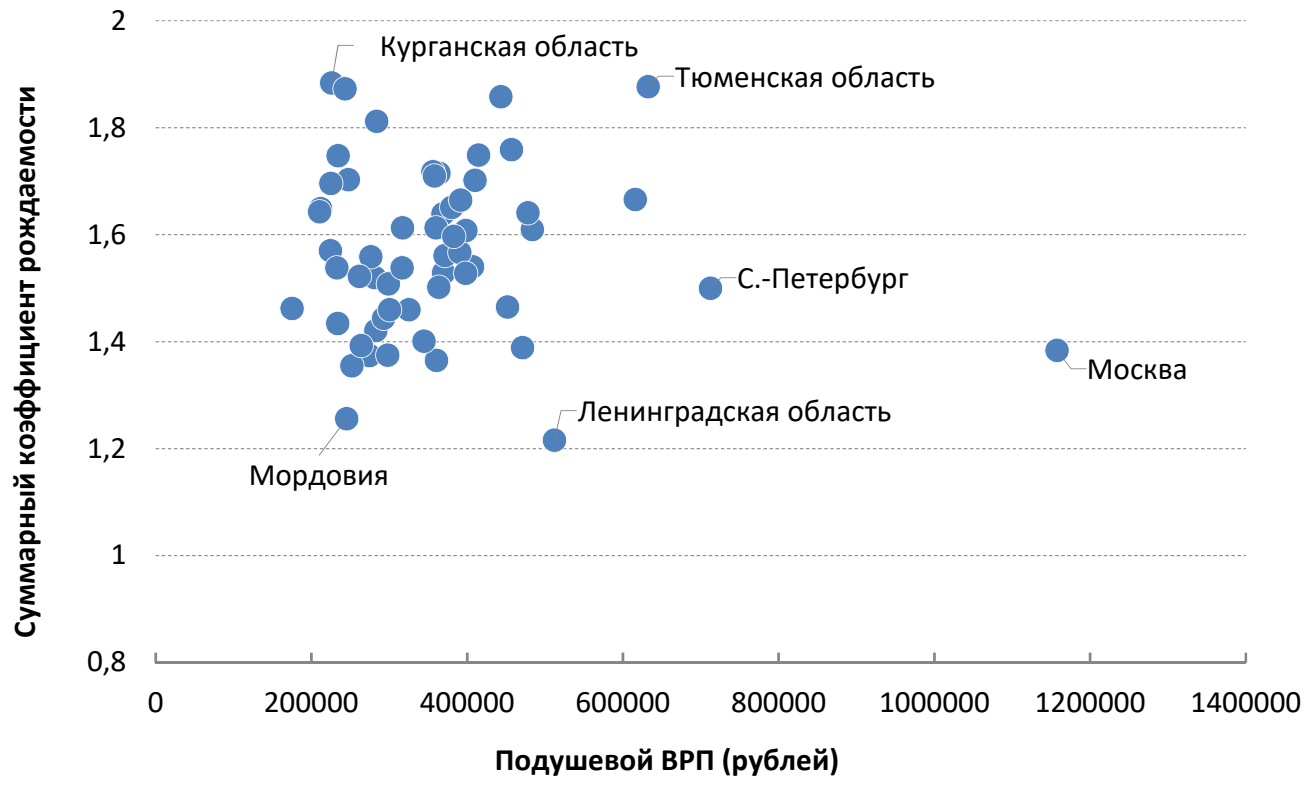

Рисунок 2. Зависимость СКР (2017 г.) от подушевого ВРП.

«Автономность» показателей ВРП и рождаемости наглядно демонстрирует ситуация в северокавказских автономиях РФ (табл. 1), большинство которых с социологической точки зрения относятся к числу традиционных обществ.

Таблица 1

Подушевой ВРП и СКР в республиках Северного Кавказа, 2017 г.

\begin{tabular}{|l|r|r|r|r|r|r|r|}
\hline Показатели & $\begin{array}{c}\text { Калмы- } \\
\text { кия }\end{array}$ & Дагестан & $\begin{array}{c}\text { Ингуше- } \\
\text { тия }\end{array}$ & $\begin{array}{r}\text { Кабардино } \\
\text {-Балкария }\end{array}$ & $\begin{array}{r}\text { Карачаево- } \\
\text { Черкессия }\end{array}$ & $\begin{array}{c}\text { Северная } \\
\text { Осетия }\end{array}$ & \multicolumn{1}{|c|}{ Чечня } \\
\hline $\begin{array}{l}\text { Подушевой } \\
\text { ВРП, руб. }\end{array}$ & 201406,9 & 197141 & 106756,6 & 153710,9 & 156602,4 & 178390,3 & 118696,4 \\
\hline СКР & 1,541 & 1,908 & 1,772 & 1,612 & 1,429 & 1,751 & 2,73 \\
\hline
\end{tabular}


Наиболее высокий суммарный коэффициент рождаемости наблюдается в Чечне (2,73), имеющей одно из самых низких значений подушевого ВРП (118,7 тыс. руб.). Высокая рождаемость фиксируется и в Дагестане $(1,9)$, ВРП которого является одним из самых высоких в регионе (197,1 тыс. руб.), уступая лишь Калмыкии. Последняя демонстрирует противоположный пример, имея самый высокий в регионе уровень ВРП (201,4 тыс. руб.) и занимая предпоследнее место по показателям рождаемости $(1,5)$ (табл. 1$)$.

В целом же сопоставление подушевого ВРП и СКР в республиках Северного Кавказа подтверждает тезис об опосредованном влиянии уровня экономического развития на рождаемость, которая в традиционных обществах определяется не доходами, а исторически сложившимися представлениями о семье, браке и количестве детей, то есть устойчивыми традициями репродуктивного поведения.

Анализ взаимосвязи естественного прироста населения за 2005-2017 гг. и подушевого ВРП (2016г.) (рис. 3) прямой зависимости между этими показателями не обнаруживает. Тем не менее в группе регионов с большой естественной убылью населения наблюдается низкий подушевой ВРП. К тому же в субъектах РФ с высоким уровнем ВРП демографическая ситуация гораздо более благополучная, хотя показатели прироста населения в них заметно различаются. Так, для Москвы, лидирующей по ВРП, характерна низкая рождаемость, но одновременно низкая смертность и небольшая убыль населения. Высокий уровень естественного прироста населения отмечен в Тюменской области и Забайкальском крае. В целом же регионы с высоким подушевым ВРП, составляющим не менее 600000 руб., демонстрируют либо прирост, либо незначительную убыль населения.

1400000

1200000

Москва

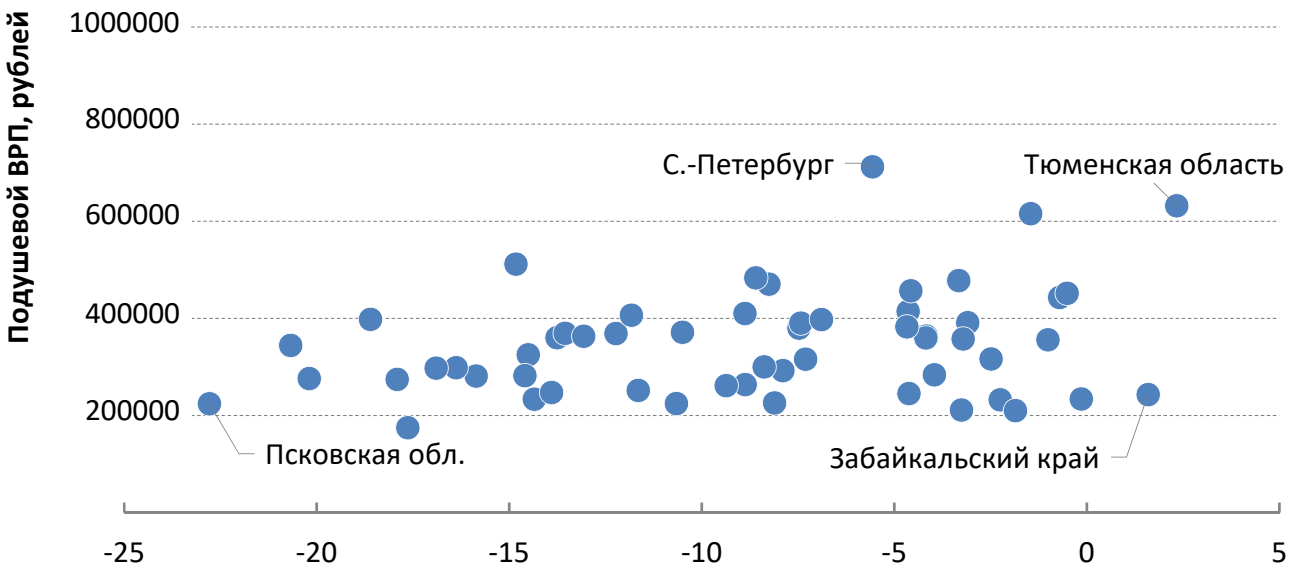

Естественная убыль/прирост \%

Рисунок 3. Зависимость естественного прироста населения от подушевого ВРП. 
Примечательно, что зависимости также не прослеживается между ВРП и таким интегральным демографическим, социальным и экономическим показателем, как ожидаемая продолжительность жизни (рис. 4). Отсутствие взаимосвязи между этими показателями наблюдается во всех федеральных округах, кроме Центрального $\left(\mathrm{R}^{2}=0,83\right)$, где ее наличие объясняется значительным отрывом Москвы от других регионов по обоим параметрам (ВРП и ожидаемой продолжительности жизни). Более высокая продолжительность жизни в столице объясняется как минимум двумя причинами: стягиванием в Москву молодежи, привлекаемой возможностью получить высшее образование и более высокими доходами, а также уровнем развитием системы здравоохранения, по которому Москва на порядок опережает другие субъекты РФ.

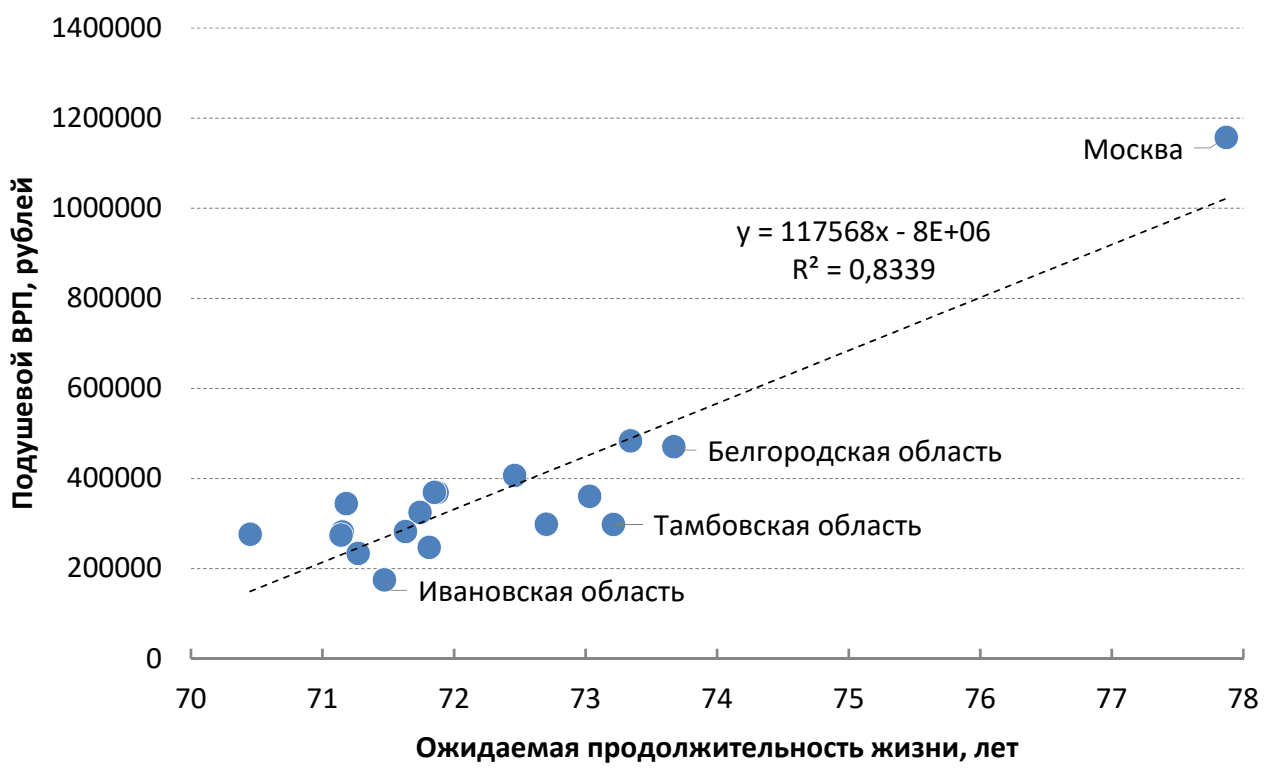

Рисунок 4. Зависимость уровня ВРП от ожидаемой продолжительности жизни в 2017 г.

\section{Миграция}

Миграционный прирост населения за 2000-2017 гг., напротив, демонстрирует наличие взаимосвязи с подушевым ВРП. Чем выше уровень ВРП, тем более притягательным является регион для переселенцев и тем выше миграционный прирост его населения. Правда, общую картину несколько портит Москва: при высоком уровне ВРП она могла бы, находясь на линии тренда, то есть развиваясь в «нормальных» условиях, без инфраструктурных и прочих ограничений, иметь более гораздо высокий миграционный прирост населения.

Одной из ключевых причин, сдерживающих дальнейший приток населения в Москву, судя по всему, является низкий показатель общей площади жилья, прихо- 
дящейся в среднем на одного жителя столицы. В Москве этот показатель - один из самых низких в России и составляет всего 19,3 кв. м, тогда как в среднем по РФ 25,2 кв. м, по ЦФО - 26,5 кв. м, а в С.-Петербурге - 24,9 кв. м. Низкая обеспеченность жильем является одной из главных причин того, что в Москве, имеющей более высокий ВРП по сравнению с С.-Петербургом, наблюдаются те же показатели миграционного прироста. Следовательно, низкий уровень обеспеченности жильем, несмотря на высокий уровень подушевого ВРП и доходов, выступает в качестве ограничивающего миграционный прирост населения фактора. Другими сдерживающими иммиграцию факторами являются ограничения по социальной и прочей инфраструктуре.

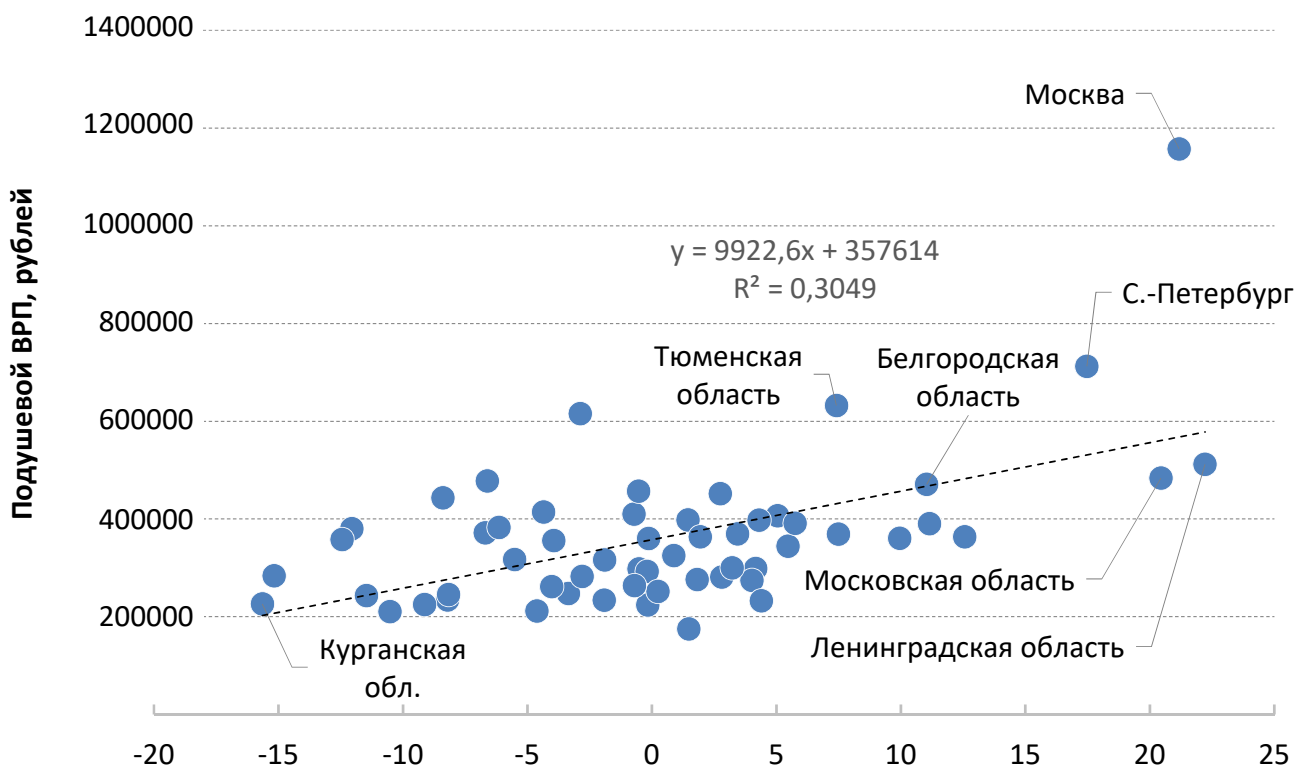

Миграционный прирост, 2000-2016 гг. \%

Рисунок 5. Зависимость миграционного прироста населения (2000-2017 гг.) от подушевого ВРП.

Характерно, что обеспеченность жильем в Московской области (31,8 кв. м на человека) значительно выше, чем в столице. Причина этого вполне очевидна: в Москве имеются значительные ограничения на новое строительство, в то время как в области поддерживаются стабильно высокие показатели ввода нового жилья, в результате чего часть нереализованного спроса реализуется в Подмосковье.

Тем не менее Москва является главным в России центром притяжения внутренних мигрантов. В 2000-2017 гг. миграционный прирост населения столицы составил около 20 \% от общей численности ее жителей. Если бы миграционная ситуация на протяжении всего этого периода развивалась в «нормальных» условиях, то есть без существующих в реальности жилищных, инфраструктурных и прочих ограниче- 
ний, то вместо 20 \% миграционный прирост населения составил бы 50-60 \% от численности населения города. В абсолютном выражении это означает 3-4 млн «дополнительных» мигрантов, которые пополнили бы население столицы.

На основе анализа данных выборки можно сформировать следующий обобщенный социально-экономический портрет регионов (табл. 2), для которых характерен миграционный приток населения или же его небольшой отток (в пределах 3 \%):

- подушевой ВРП выше среднего (среднеарифметический - 362 тыс. руб., в регионах с положительным миграционным приростом - 407 тыс. руб.);

- наличие крупных городских агломераций;

- географическое расположение в европейской части страны, к югу от Москвы;

- наличие поблизости регионов или стран, выступающих в качестве миграционных «доноров».

Противоположным примером может служить Свердловская область, которая, судя по всему, испытывает миграционный отток населения из-за особенностей своей экономической географии - ее окружают регионы с достаточно высоким ВРП. К тому же для Уральского федерального округа в целом также характерен миграционный отток населения в западную часть России

Факторы, вызывающие отток населения, не обязательно присутствуют в каждом субъекте РФ, но, как правило, являются типичной чертой регионов с миграционной убылью населения.

В целом регионы, вошедшие в выборку, можно разделить на 2 группы:

- субъекты РФ с положительным миграционным притоком, к числу которых относятся 27 краев, областей и республик со среднедушевым ВРП в размере 407 тыс. руб. (исчисленным как среднеарифметическое). 24 из них расположены в европейской части России (9 первых мест в рейтинге полностью занимают регионы Центральной России).

- 30 регионов с миграционной убылью, 13 из которых расположены в Уральском, Сибирском и Дальневосточном округах. При этом из 10 субъектов РФ, занимающих в рейтинге последние места, только 4 находятся в центральной России. Средний ВРП регионов с миграционной убылью составляет 362 тыс. руб., а в 10 регионах с наибольшей миграционной убылью населения среднедушевой ВРП равен всего 285 тыс. руб.

То есть увеличение уровня подушевого ВРП относится к числу факторов, способствующих повышению миграционной привлекательности региона. И чем выше уровень ВРП на душу населения, тем выше миграционная привлекательность территории. Увеличивая свой экономический потенциал, регионы решают как минимум две демографические задачи: сдерживают отток своего населения и привлекают жителей других субъектов РФ, стремящихся туда, где выше доходы и уровень жизни.

Существенную роль в миграционной притягательности региона играет и географический фактор, который может быть даже более значимым, чем экономический. Так, в Ивановской области, подушевой ВРП которой, по данным за 2016 г., составляет 174 тыс. руб., на протяжении 2000-2017 гг. зафиксирован миграционный прирост населения в размере 1,4 \%. При этом в соседней Костромской области, подушевой ВРП которой почти в полтора раза больше (247 тыс. руб.), миграционная убыль населения за этот же период составила -3,3 \%. Как представляется, одной из причин оттока населения является географическая отдаленность небольших населенных пунктов Костромской области. 

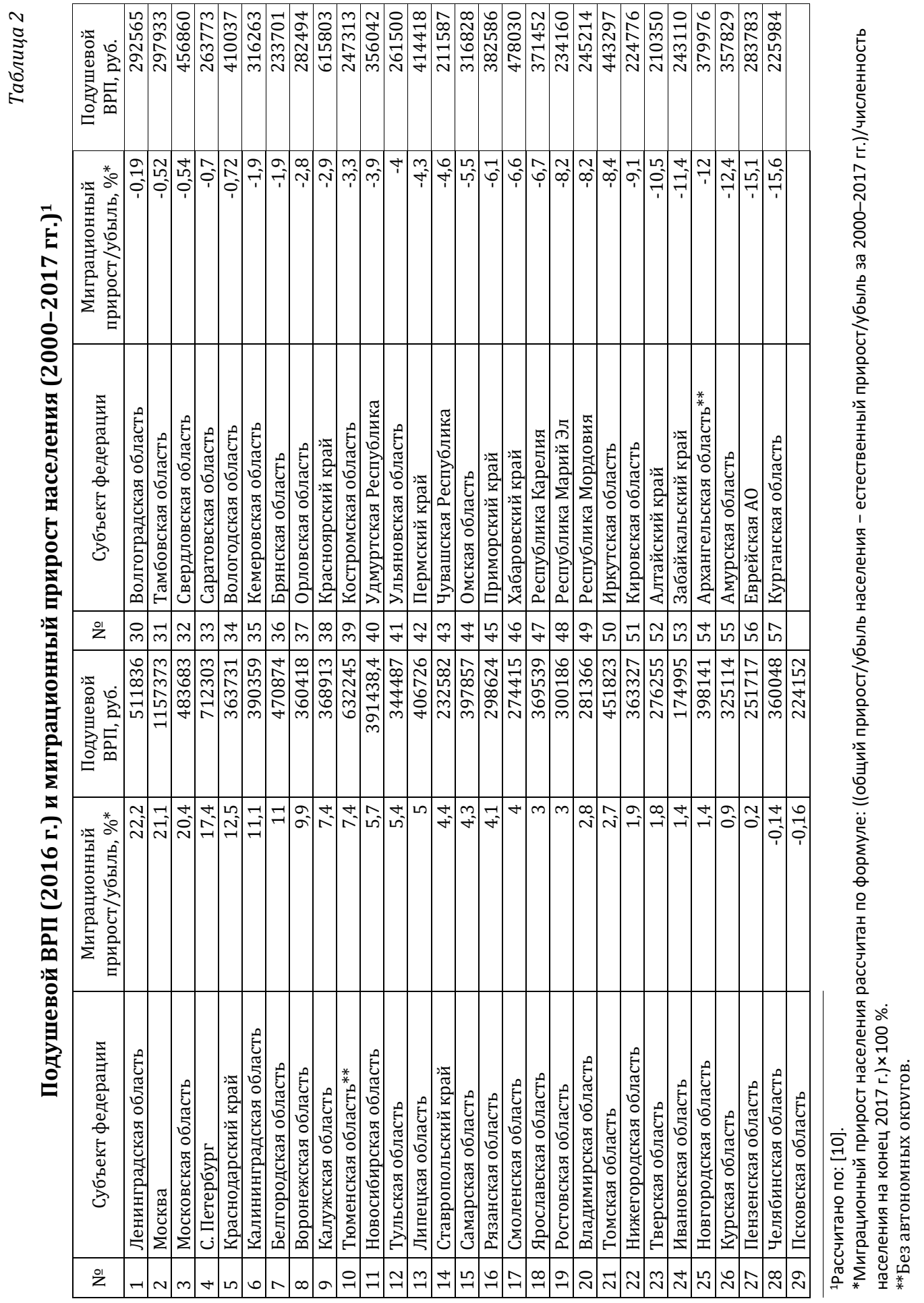


\section{Классификация регионов}

Сопоставление естественного и миграционного прироста населения регионов России, включенных в выборку, позволяет разделить их на четыре группы. К первой из них относится Тюменская область, которую отличает положительный естественный, миграционный прирост и высокий подушевой ВРП (рис. 6).

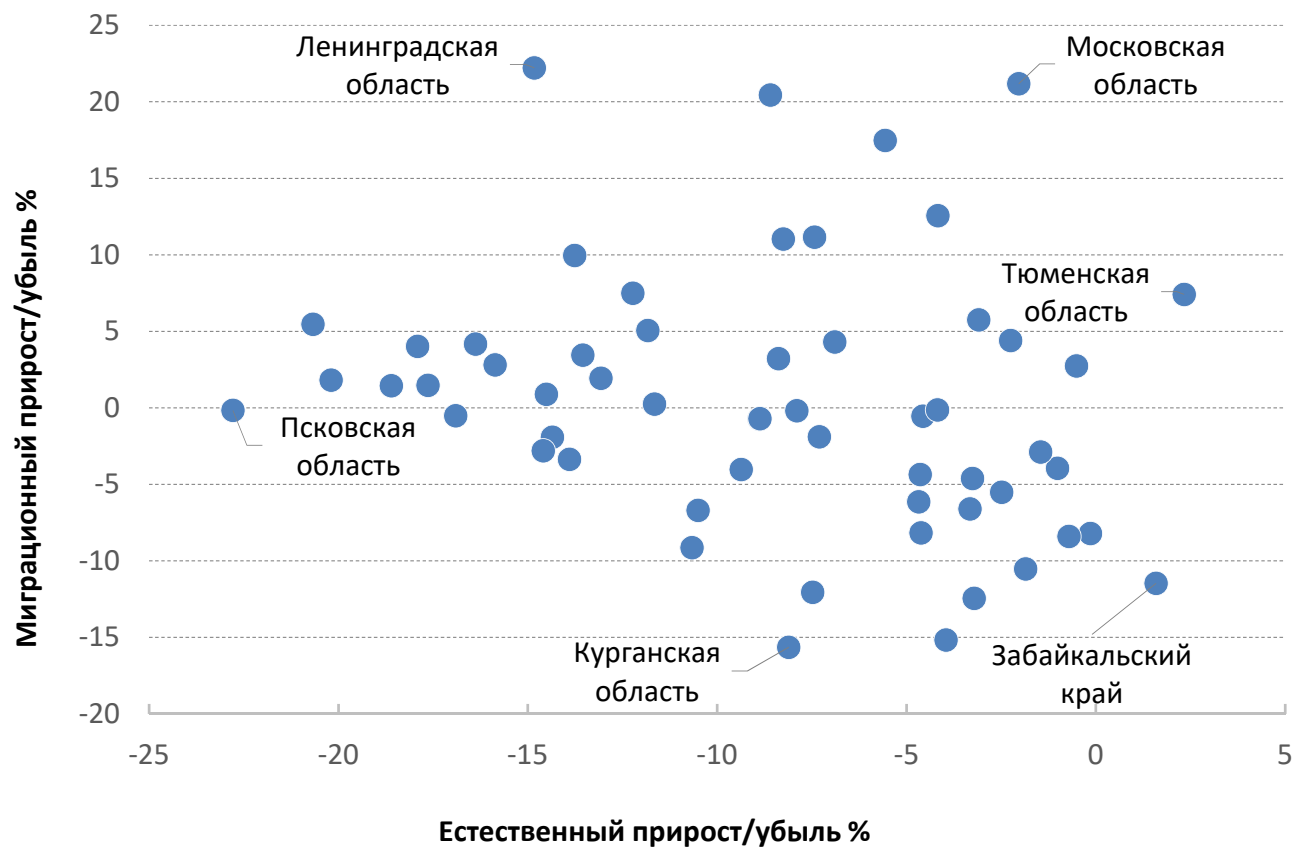

Рисунок 6. Зависимость естественного прироста населения регионов РФ от миграционного прироста (2000-2017 гг.)

Вторая группа включает 26 регионов, в которых наблюдается отрицательный естественный, но положительный миграционный прирост населения и относительно высокий ВРП. Наиболее многочисленной является третья группа, к которой относится 29 регионов с отрицательным естественным, миграционным приростом населения и уровнем подушевого ВРП ниже, чем во второй группе. К четвертой группе, включающей регионы с положительным естественным, но отрицательным миграционным приростом и низким подушевым ВРП, относится Забайкальский край.

Большинство областей Центрального федерального округа, представляющего собой историческое и демографическое ядро России и русского народа, относится ко второй группе регионов, имеющих за 2000-2017 гг. положительный миграционный и отрицательный естественный прирост населения. Его отток наблюдается лишь в четырех регионах - Брянской, Костромской, Орловской и Тамбовской областях (рис. 7). Значительное влияние на миграционную ситуацию в ЦФО оказывает территориальная близость к субъекту РФ, лидирующему по уровню социально-экономического развития. Так, например, в Ивановской и Костромской областях, расположенных недалеко от Москвы, еще в последние десятилетия советского периода 
наблюдался естественный прирост населения и его общая убыль вследствие миграционного оттока в столицу и другие регионы [1].

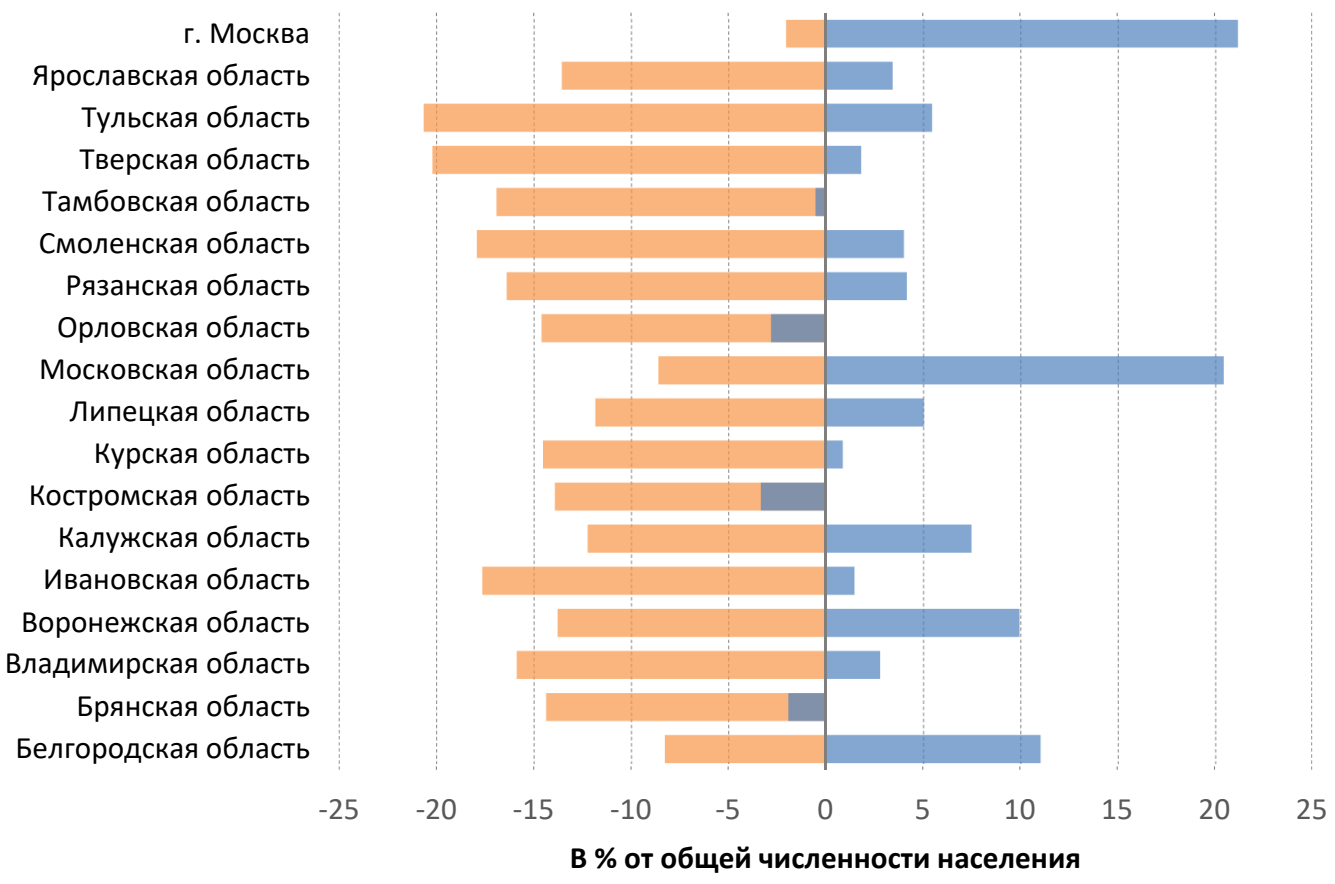

Миграционный прирост/ убыль \% — Естественный прирост/убыль \%

Рисунок 7. Структура прироста населения по ЦФО (2000-2017 гг.).

В то же время утверждение, что экономический рост может вызвать приток мигрантов [2, с. 85], выглядит несколько упрощенным. В целом анализ взаимосвязи миграционного притока населения и роста подушевого ВРП в Центральной России (рис. 8) наличие зависимости между ними подтверждает. В регионах, где рост ВРП выше, более значительными являются и показатели миграционного прироста населения.

Лидером по этому показателю является Московская область, которая пользуется преимуществами «пристоличного» региона, не имея при этом столь же значительных, как в Москве, ограничений по стоимости жилья. Большой поток мигрантов направляется в Белгородскую область, что объясняется иммиграцией с Украины (от Белгорода до Харькова всего несколько десятков километров), а также высокими показателями ВРП.

При этом из общей картины, рисуемой соотношением миграционного и экономического роста, выбивается Москва. Но связано это с тем, что мигрантов привлекает не рост ВРП как таковой, который они ощущают лишь опосредованно, а наличие высокого уровня доходов в данный момент времени. Москва же сохраняет значительное лидерство по подушевому ВРП благодаря его изначально более высокому уровню. За 18 лет прочим субъектам РФ удалось лишь незначительно сократить этот разрыв. Поэтому конкурировать со столицей по миграционной привлекательности, даже имея более высокий рост ВРП, другие регионы пока не в состоянии. 


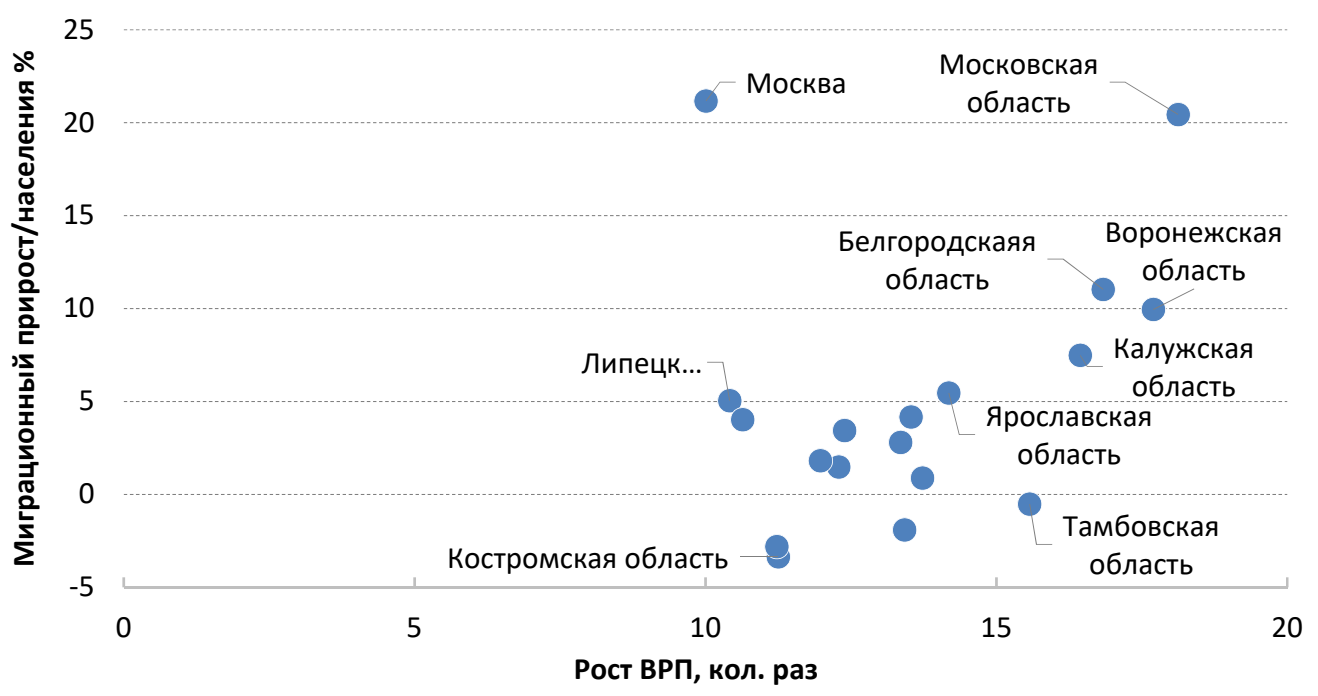

Рисунок 8. Зависимость миграционного прироста в ЦФО от роста ВРП, 2000-2017 гг. (ВРП 2016 г. / ВРП 2000 г.).

Таким образом, зависимость между ростом экономики и миграционной привлекательностью региона имеет непрямой, опосредованный характер. Даже в тех регионах, где наблюдается высокий экономический рост, вновь создаваемые рабочие места с высокой добавленной стоимостью (и уровнем доходов) могут идти на замещение низкооплачиваемых рабочих мест, не увеличивая их общее количество или же увеличивая его незначительно. Поэтому можно согласиться с утверждением о том, что перераспределение трудовых ресурсов между регионами является прерогативой социально-экономической, а не миграционной политики [11, с. 25].

\section{Выводы}

По итогам проведенного исследования можно сделать вывод о наличии значительной зависимости между подущевым ВРП и миграционным притоком населения и, напротив, отсутствии такой зависимости между ВРП и естественным приростом населения. То есть развитие экономики практически не оказывает влияния на рождаемость, которая определяется другими факторами и главным образом системой ценностей, а в традиционных, аграрных обществах - сохранением традиционной многодетной семьи. На миграцию же социально-экономическое развитие влияет опосредованно - через рост доходов, которые определяют миграционную привлекательность региона. Влияние подушевого ВРП на ожидаемую продолжительность жизни присутствует лишь в том случае, когда регион-лидер значительно опережает другие регионы по этому показателю, и во многом связано с инвестициями в развитие социальной инфраструктуры и системы здравоохранения.

Главным фактором, привлекающим переселенцев, являются высокие доходы, которые достижимы лишь при условии высокого уровня ВРП. Поэтому рост экономики влияет на миграционную привлекательность региона не напрямую, а через рост доходов его жителей. В то же время притягательность региона для мигрантов 
определяется и другими факторами: географическим положением, климатом, уровнем развития инфраструктуры, доступностью жилья, семейно-родственными связями. По этой причине в $3 / 4$ регионов Центрального федерального округа на протяжении 2000-2017 гг. наблюдался положительный миграционный приток, включая те из них, которые, как Ивановская область, имели низкие показатели ВРП.

В целом же уровень социально-экономического развития в значительной мере определяет миграционный приток населения и практически не влияет на рождаемость, которая в большинстве регионов России не компенсирует смертность. Из числа включенных в выборку регионов лишь Тюменская область, занимающая как нефтедобывающий регион особое положение, имеет положительный миграционный и естественный прирост населения. Что же касается методов стимулирования рождаемости, то они находятся в плоскости демографической, а не экономической политики и непосредственно связаны не с повышением ВРП, а с системой семейных ценностей, уровнем доходов и обеспеченности жильем семей, имеющих нескольких детей.

\section{Ссылки / References}

1. Рыбаковский О. Л., Таюнова О. А. Демографическая динамика регионов России и её компоненты в 1959-2017 гг. // Народонаселение. 2019. Т. 22. № 1. С. 4-20.

2. Козлова О. А., Тухтарова Е. Х. Социально-экономическое неравенство как фактор формирования миграционных потоков // Народонаселение. 2017. № 4. С. 78-90.

3. Денисенко М. Б., Николаева У. Г. Что происходит с сельским населением на ближнем севере России? (на материале Костромской области) // Социологические исследования. 2015. № 12. С. 70-81.

4. Яковлева Е. Б., Кислова О. Е. Демографическая ситуация в России и проблемы трудовой миграции // Вестник Санкт-Петербургского университета. Сер. 5. Экономика. 2015. Вып. 1. C. $5-19$.

5. Карачурина Л. Б. Межрегиональная миграция и социально-экономическая дифференциация пространства современной России // Проблемы прогнозирования 2006. № 3. C. 96-115.

6. Единак Е. А., Коровкин А. Г., Долгова И. Н. Факторный подход к прогнозноаналитическому исследованию миграционной активности населения России // Научные труды: Институт народнохозяйственного прогнозирования РАН. 2011. Т. 9. С. 398-415.

7. Гришанов В. И., Ноздрина Н. Н., Шнейдерман И. М. Роль жилья в миграционных процессах в России // Народонаселение. 2017. № 4. С. 91-101.

8. Мокренский Д. Н. Роль экономических факторов в миграционном движении населения муниципалитетов ЦФО // Государственное управление. Электронный вестник. Выпуск № 69. Август 2018 г. URL: http://e-

journal.spa.msu.ru/uploads/vestnik/2018/vipusk_69._avgust_2018_g./regionalnaja_ekonomi ka/mokrensky.pdf (дата обращения: 14.01.2020).

9. Вакуленко Е. С. Ведёт ли миграция населения к межрегиональной конвергенции в России? // Вестник НГУЭУ. 2013. № 4. С. 239-264.

10. Регионы России. Социально-экономические показатели - 2018 г. // Федеральная служба государственной статистики. URL: http://www.gks.ru/bgd/regl/b18_14p/Main.htm (дата обращения: 20.06.2019).

11. Рыбаковский О. Л., Таюнова О. А. Цели стратегии миграционного развития России // Народонаселение. 2018. Т. 21. № 1. С. 22-30. 